\title{
Contemporary Intra-Core Relations and World Systems Theory
}

Peter Gowan

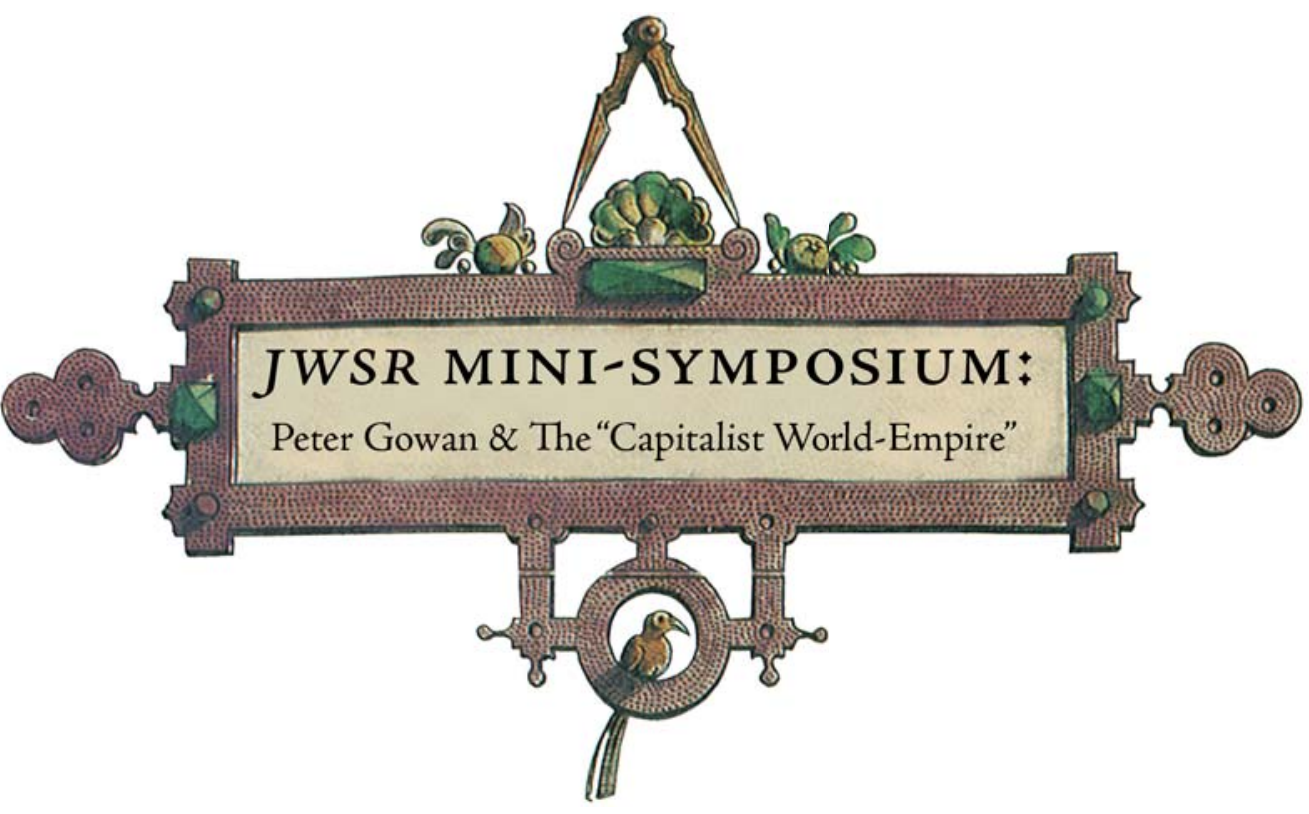

PART Iः THE THEORY OF HEGEMONY AND CONTEMPORARY CONDITIONS

ne of the great strengths of world-systems theory (шST) is the fact that it insists upon the need to analyse contemporary dynamics within a long historical perspective. It argues that we can make sense of historical continuity and change through its concepts of core/periphery relations reproducing themselves across time. And it also identifies a recurrent pattern-or series of patterns-in intra-core relations in the Modern World System since the $16^{\text {th }}$ Century involving a plurality of core powers both competing and co-operating with each other. Unlike, say, liberal international relations theory, WST sees intra-core relations as being marked by recurrent structural conflict as core powers compete with each other. But unlike realist international relations theory, wST does not derive its theory of structural conflict between core powers from purely political drives for power-maximisation on the part of states. Instead wst identifies the sources of conflict in the compulsions of capitalism as a socio-economic as well as an interstate system.

In this paper, we will accept wst's theory of the sources of structural conflict amongst core powers within what Wallerstein calls the Modern World System. Our critique will be directed towards wst's theorisation of resulting conflicts as a recurrent pattern of hegemonic cycles.

\section{ABSTRACT:}

This paper focuses upon one small region of 3. Is WsT's insistence that its concept of coreWorld-Systems Theory (WST) but one that is wide world empires cannot be established in important for analysis of the contemporary the modern world system valid? world: the dynamics of intra-core relations.

I will try to address three questions:

I. Does the wSt theory of the historically cyclical patterns of intra-core relations provide us with a persuasive framework for understanding contemporary core dynamics?

2. More specifically can the reach and depth of the power of the United States within the contemporary core be captured by wst's theory of capitalist hegemons and their rise

In addressing these issues, I will begin by outlining the general approach of wST to the analysis of intra-core relations, focusing in particular upon wst's concept of core hegemons and their rise and fall. I will then look at the arguments of WST as to why a capitalist world empire is impossible. I will then go on to examine how we might conceive of the victory of a World-Empire. And I will then turn to examine the contending situation and the character of the power of the US today.

Peter Gowan

Department of Law, Governance and International Relations

London Metropolitan University

166-220 Holloway Road

London N7 8DB

p.gowan@londonmet.ac.uk

http://www.londonmet.ac.uk/depts/lgir/

JOURNAL OF WORLD-SYSTEMS RESEARCH, X, 2, SUMMER 2004, 47I-500 http://jwsr.ucr.edu/

ISSN $1076-156 \mathrm{X}$

(C) 2004 Peter Gowan 
The Mainstream wst theory of Intra-Core Relations and Hegemonic Cycles

All the main trends in wsT agree on the idea that within the Modern World System there have been recurrent cyclical patterns in intra-core relationships. The cycles can be thought of as beginning when one core power rises to a dominant position within the hierarchy, becoming a 'hegemon' and establishing some order and stability to the core as other states adapt to the new hegemon's regime. This phase is followed by attempts on the part of other core powers to innovate and challenge the hegemon. As this challenge mounts, the core enters a phase of instability and conflict, typically resolved by intra-core wars which eventually throw up a new hegemon while the previous hegemon declines. ${ }^{1}$

Within the broad field of wST we can distinguish two contrasting emphases in the ways in which these cycles are theorised. One emphasis is close to realist theories of international relations, stressing the determinant as being the military-political capacities of core states. Writers like Modelski and Thompson along with Gilpin see the economic dimension as being subordinated to and structured by this issue of military-political capacity. But what might be called the mainstream of wst represented by Wallerstein, Chase-Dunn and Arrighi emphasise capitalist economic systems as the determinant element in the competition, understanding these economic systems in a Marxist sense as production systems generating streams of surplus value. They by no means ignore the role of military-political power but they view its role as an indispensable support for the struggle for dominance at the level of production. Thus we can summarise their theory of the hegemonic cycles as having two main components:

a. A constant search by a plurality of core powers to gain dominance in the most sophisticated and desirable capital-intensive products. Hegemons are those capitalist powers which achieve dominance in this production field thus positioning themselves at the top of the international division of labour, penetrating the markets of other core states, gaining the largest streams of surplus value and being able to set the framework for other core states in the economic field.

I. WST authors have also noted and explored other cyclical patterns and regularities such as: regularities of quantitative economic cycles-Kondratief waves, with their A Phase of growth and their B phase of depression. They link these K-waves with theories of co-operation/tension within the core; and quantitative regularities in the cycles of core warfare. But we will not consider these issues here. b. Military-political action is viewed mainly as a buttress or support for this economic dominance, protecting the core economy from external attack or internal challenge and removing obstacles to the flow of its products across the system (Wallerstein 1984).

It is this very specific definition of hegemony which results in the wST's mainstream identification of the three hegemonic powers as Holland, Britain and the United States. The military-political perspective of Modelski and Thompson focuses on sea power rather than dominance in capital-intensive commodities as the key to hegemony and this gives Portugal a place on the list before Holland. But with either version we should note that the idea of hegemonic cycles in the core derives from the identification of hegemons and their fates.

This mainstream WST conception is perfectly coherent internally. But it is important to note that it employs a highly restricted concept of hegemony and one anchored in production systems. It is on the basis of that specific and restricted concept of hegemony that WST can derive its historical chain of hegemons and the cyclical patterns of their rise and decline. But wst also, as an inevitable consequence of its specific theory of hegemonic cycles, downplays other aspects of intra-core relations and is predisposed towards certain expectations of the contemporary dynamics rather than others. Three specific consequences of these kinds are important:

a. The equation sign between the three powers designated as successive hegemons tends towards downplaying some radical differences between the three hegemonies in terms of the type of capitalism, in the nature of the core context in which the hegemons operate and the distinctive political capacities of the successive hegemons.

b. It tends to downplay the possibility that a hegemon with great political capacities may be able to exploit feedback mechanisms from the interstate system onto productive systems other than the traditional feedback mechanisms of intra-core wars.

c. It predisposes Wallerstein, Chase-Dunn and Arrighi in their analysis of contemporary developments in the I980s and I990s to view the US as having entered a phase of hegemonic decline after its dominance in capital intensive production for core markets was challenged by German and Japanese capitalism in the I970s. 


\section{The US as a Sui Generis Hegemonः Is it a Cycle-Breaker?}

Wallerstein, Chase-Dunn and especially Arrighi do, of course, note various differences between the successive hegemonies both in terms of their own attributes and the contexts in which they have operated. But they have underestimated the qualitative differences between the US and Britain either by overplaying British power in the $19^{\text {th }}$ century or by underplaying US power in the second half of the twentieth century or both. They have thereby tended to ignore the possibility that the peculiarities of US hegemonic capacities could disrupt the cyclical pattern by which wst has characterised core dynamics. We will briefly outline some central peculiarities of US hegemony since 1945:

\section{The Unipolar Core}

Since 1945 US dominance within the core has been qualitatively different from that of Britain in the $19^{\text {th }}$ century, not to speak of Holland in the $17^{\text {th }}$ century.

The political dimension of the Britain-core relationship in the $19^{\text {th }}$ century and the US-core relationship in the second half of the $20^{\text {th }}$ century has been radically different. The British relationship was marked by balance of power mechanisms-political multipolarity; the American relationship since 1945 has been marked by political unipolarity.

Britain never could, and never tried to, suppress political multipolarity within the core. Apart from ensuring the security of its access to the continent through the Scheldt and Belgium, Britain had only a 'negative' political goal within the continental core: that of ensuring that no single continental power dominated the continent. Britain's lack of both political capacity and political ambition to dominate the continental core was an important reason why Britain was accepted as the leader of the international political economy by other core powers. That leadership operated within a balance of power international political mechanism.

Since 1945, the US has suppressed the balance of power mechanism within the core, brigading all other core powers into essentially bilateral security alliances dominated by the US and taking over political leadership functions of the other core powers in the field of international politics. A hub-and-spokes structure of intra-core political/military relations thus ensued after 1945, with the primary political relationship of each core power being its subordinate link with Washington. There were, of course, variations in this political subordination: it was most marked in the case of the two other strongest core economies, Germany and Japan, less marked in the case of France. We will look at the modalities of this US political dominance later, but there is surely no doubt that it constitutes a radical difference with the British $19^{\text {th }}$ century case and it is not just a difference in the quantitative power resources of the hegemon: it is a radical difference in the structure of intra-core politics.

\section{The Structural Character of US Political Subordination of the Core}

US political dominance over the core does not simply derive from the US's quantitatively greater military power resources. It derives from how those military resources are deployed to politically shape the foreign and security policy context facing other core states. By shaping this context the US has indirectly shaped the actual substance of the foreign policies of other core states. Let us note some key features of this shaping activity:

a. The US has the ability to shape and control the regional strategic environment of the West European powers and Japan. In the case of Western Europe this has been achieved through making Western Europe strategically dependent upon the US-Soviet and now US-Russia relationship; in the case of Japan through making it dependent first on the US-Soviet relationship in the Cold War but now also on the US-China relationship. This strategic dependence of the allies is re-enforced by the Treaty obligations on both Germany and Japan not to develop their own strategic nuclear capacities. It may be further re-enforced by US development in the future of anti-ballistic missile capacities. Insofar as neither Germany nor Japan can break out of this strategic dependence on the relationship between the US and their neighbouring nuclear powers, their security is dependent upon the US.

b. The US has the ability to control, through its military-political reach, the regional peripheries of its major allies. In the West European case, the US has long controlled the Mediterranean area and it now also has extended its military-political predominance across South East and Eastern Europe through both NATO enlargement and the Partnership for Peace as well as through bilateral agreements. On the Pacific Rim it has important military-political bridgeheads in South Korea, South East Asia and privileged security relationships with Australia and New Zealand. As a result of this US military-political predominance in the hinterlands of the other core centres, it can steer events in those hinterlands to the benefit or detriment of those core regions. And it can do so either to the benefit, or to the detriment of these other core states. The US has demonstrated this capacity rather dramatically in the Yugoslav wars of the I99os: from its refusal to use its resources to maintain Yugoslav unity in 1990-199I, to its drive for a unitary independent Bosnia (entailing a Bosnian war) at the start of 1992, to its success in persuading the Bosnian government to reject EU efforts to bring the war to an end, to its readiness to bring the war to 
an end once the EU states had accepted the dominance of NATO in the Yugoslav and wider European theatres, to its capacity to lead the EU states into a war with the Yugoslav state in 1999. The US has similarly acquired predominant regional military-political influence over such parts of the Japanese hinterland as the Philippines, Thailand, Indonesia, Taiwan and South Korea.

c. The US has the ability to control the sources of and transport routes for crucial energy and other strategic materials supplies needed by its allies, through its positions in the Middle East and its sea and air dominance in the Mediterranean, the Indian Ocean, the Pacific and the Atlantic (it has also, of course, been seeking to extend its control into the Caspian area in the recent past). Interruptions of supplies can have very grave consequences for the other core states, but they are dependent upon the US to assure these supplies.

d. Very importantly, it has also had the capacity to homogenise the political cultures of its allies around sets of political values articulated to serve US interests, symbolic structures rooted in the US victory over Japan and Germany in the second world war embodying such highly sensitive symbols as 'Munich,' 'Hitler,' ethnicist nationalism and exterminism, totalitarianism versus freedom, democracy, individual rights, one universalist humanity, etc. This value structure has been repeatedly and effectively embedded within the national political cultures of its allies through repeated international political polarisations during and after the Cold War (notably recently in the drive against Iraq and in the various Yugoslav wars). It is a structure of political values which throws the main allied powers (Germany and Japan) into a very vulnerable international position and it has also repeatedly demonstrated the US's capacity to trump the rival potential centre of internationalist liberal and democratic universalism, France.

Taken together these four US capacities have reduced the foreign policy and power projection autonomy of its allies to near zero. This marks, at the very least, a profound, structural modification in the inter-state system in comparison with earlier epochs. Behind unipolarity lies a series of structural dependencies of other core states upon the US for their political security.

\section{The Regime-Making Capacities of the United States}

WST argues that each hegemon establishes an international regime of accumulation suited to its dominance in a particular set of capital intensive commodities and the other core powers adapt to that regime and then launch a competitive challenge within it. The regime then is eventually reshaped through intra-core wars. But there have been striking differences between the regimemaking capacities of the US and of Britain.
Britain established both a regime for trade and a regime for monetary relations: the Free Trade principle and the Gold Standard principle. But the other core powers were not brigaded by British power into accepting these regimes. They 'voluntarily' accepted them (or didn't, as the case may be). And Britain unilaterally committed itself to these regimes: free trade was a unilateral decision by Britain, not a reciprocal bargain; and the same was true of the Gold Standard.

The USA has been able to operate quite differently: it has imposed international regimes on the other core powers and has had the capacity both to stand above its own international regimes and to adapt them to suit its perceived interests or to create entirely new regimes.

a. Trade Regimes: Thus the USA was never a unilateral free trader. It has adopted the ideology of free trade in the post-war period but it has restricted its implementation in very important ways and has continually demonstrated its readiness, if necessary, to flout free trade principles and pursue a policy of reciprocity rather than most favoured nation (MFN) status in trade relations. At the start of the 1990s the GATT was the embodiment of free trade principles but it was far from being the organiser of actual trade relations as a whole: on some estimates it embraced no more than about $5 \%$ of all international trade.

Thus the US has both presided over a (partial) free trade regime for the rest of the world and simultaneously given itself the right both to control the scope of that regime and to flout its own regime, where necessary, to suit its own interests.

This pattern has been applied throughout the post-1945 period and has been very evident in relation to the major institutional development in the field of economic relations in the I990s: the emergence of the WTO. The US Congress's ratification of the WTO Treaty explicitly makes US acceptance of its jurisdiction conditional upon the WTO's being 'fair' to US interests. And all who follow international trade policy know that the word 'fair' in this context means serving and defending US economic interests. And for successive US administrations since the late 1980 s this conditional general stance towards the GATT/WTO has been combined in US trade policy, with explicit determination to flout GATT/WTO rules where these are deemed 'unfair' to US interests, an approach which Jagdish Bagwati has aptly called 'aggressive unilateralism.' Bagwati highlights the creation and use of the so-called Super 301 and Special 30r laws, but to these could be added other instruments of US unilateralism on international economic law, such as its use of anti-dumping instruments and countervailing duties. All these instruments have been placed in the service of US claims to have unilateral national authority to judge which kinds of behaviour by other states in economic policy are 'unfair' to the US, regardless 
of what rules are laid down within the GATT/WTO framework. And the use of these instruments has been far from marginal in US international economic policy. As Miles Kahler (1995) points out, side 'the number of actions brought against 'unfair' trading practices-anti-dumping, countervailing duties (subsidies) and section 30I-increased dramatically' during the I990s (P. 46). In the words of Pietro Nivola (1993) 'no other economic regulatory programme took on such an increase in case-loads' (P. 2I).

And this refusal to be bound by global economic law has been combined with vigorous attempts in some fields to extend the jurisdictional reach of US domestic economic laws internationally, applying it to non-American corporations operating outside the United States. Of actions in this field, Kahler (1995) reports that 'Here the list was long' ( $P+46)$.

b. International Monetary Relations: the contrast is equally striking and structurally similar in international monetary relations. The international monetary system established at Bretton Woods was always conditionally and partially implemented and although it did begin with the US accepting a discipline upon its dollar policy through the gold link, when that discipline was perceived by the US government in the I970s to be detrimental to US interests it was simply scrapped through unilateral action by the US against opposition from all other core states and from then on the international monetary system became a pure dollar standard, thus manipulable by the US government as it wished.

This dollar standard international monetary system has enabled the US to escape from the usual balance of payments constraints upon a state's economic management and also enabled the US to escape the consequences of large swings in dollar exchange rates with other currencies, such as the Dmark and the Yen. It has thus been able to swing the dollar up or down against other currencies in line with purely US economic or political objectives.

John Williamson (1977), an insider in the diplomacy that led to the US's imposition of the dollar standard in the mid-I97os has expressed what was at stake clearly: "The central political fact is that a dollar standard places the direction of world monetary policy in the hands of a single country, which thereby acquires great influence over the economic destiny of others. It is one thing to sacrifice sovereignty in the interests of interdependence; it is quite another when the relationship is one way. The difference is that between the EEC and a colonial empire.... The fact is that acceptance of a dollar standard necessarily implies a degree of asymmetry in power which, although it actually existed in the early post-war years, had vanished by the time that the world found itself sliding to a reluctant dollar standard" (P. 37). c. International Financial Regimes: The same pattern has applied to the international financial regime: when the US government decided that the Bretton Woods system of state control of international financial control was detrimental to US interests, it had the capacity in the I97os to transform the regime, placing international financial flows in the hands of private financial operators and markets, and placing New York as the international financial centre from the early I980s. Since the I970s it has also involved effectively dismantling the financial regimes of its allies (ending capital controls).

d. Product and Asset Market Regimes: US regime-shaping capacities have extended also to all other areas of international economic flows and international markets. Markets are often treated as if they were spheres of exchange autonomous from state policy, but in the modern world they are highly complex mechanisms grounded in intricate networks of public and private law, institutions and conventions. The state executives and big businesses of the core states work together to seek to shape markets in their own interests. And in this field the US has demonstrated great and continuing influence. Since the launching of the Uruguay Round in the mid-1980s it has been engaging in an extremely wide-ranging and remarkably successful effort to restructure both product and asset markets within other states, bringing their legal rules and institutions into line with the perceived interests of US business expansion into those states. These so-called 'behind the border' international regimes are another distinctive feature of the phase of US hegemony.

Giovanni Arrighi, who, more than other wst theorists, has understood some crucial distinctive features of US global power, provides us with an interesting perspective on this. He calls American capitalism 'autocentric' in its relation to the international political economy, while British capitalism was, in an important sense, shaped by the distinctive relationship of each of its parts with the world economy. The 'autocentric' character of US capitalism-made possible not only by its internal characteristics but also by its extraordinary power vis a vis the rest of the world explained above, has involved an ambitious agenda of, in Arrighi's words, 'internalising the world economy within and in line with the structures of American capitalism.' Arrighi stresses internalisation within the organisational domains of US MNCs: but US restructuring of the social relations of production abroad has been far more extensive than that.

We do not wish to suggest that these capacities to restructure the internal regimes of its allies have been absolute-absolutely not. And we will not, at this stage consider how extensive they have been.

This international regime-shaping capacity in the international political economy has been, of course, linked to the overwhelming military-political 
dominance of the USA over the core discussed earlier. Both have given the USA historically egregious power capacities enabling it to respond assertively to the challenges to its hegemony in the field of capital intensive production, using its strength outside this field to strike back on many fronts in order to prepare the way for its hegemonic restoration in the productive field. These feedback effects have not applied to other core powers and have not been given due weight by wst authors, although Arrighi has been sensitive to some important aspects of them.

\section{US Feedback Mechanisms for Cycle-Breaking.}

wst's focus upon a definition of hegemony centred upon production systems has thus been combined with an inadequate stress on the mechanisms available to the US and not available to earlier hegemons for responding to challenges from core competitors in the sphere of production and striking back. We can think of these mechanisms as a kind of feedback from outside the productive sector onto the course of events within the productive sector. The most important of these mechanisms has been the US's extraordinary military-political reach; but also of great importance has been its power of the monetary-financial system. Both these mechanisms have given the US the ability to change and rechange the rules of the game in the sphere of production and commodity exchange in order to create the conditions for rebuilding US hegemon in the narrow sense in which it has been used by wst.

The potency of the military-political levers during the Cold War has been stressed by Samuel Huntington (1973) in an important article in the 1970s:

Western Europe, Latin America, East Asia, and much of South Asia, the Middle East and Africa fell within what was euphemistically referred to as 'the Free World' and what was, in fact, a security zone. The governments within this zone found it in their interest: (a) to accept an explicit or implicit guarantee by Washington of the independence of their country and, in some cases, the authority of the government; (b) to permit access to their country to a variety of US governmental and non-governmental organisations pursuing goals which those organisations considered important....The great bulk of the countries of Europe and the Third World....found the advantages of transnational access to outweigh the costs of attempting to stop it (P. 344).

And as David Rothkopf (1998) has added, in the post-war years "Pax Americana came with an implicit price tag to nations that accepted the US security umbrella. If a country depended on the United States for security protection, it dealt with the United States on trade and commercial matters."
A very important indirect effect of US military-political capacity has been its control over energy and strategic mineral sources and transport routes, the most dramatic example being its use of the oil price rises in the early I970s.

The potency of the monetary-financial levers has been equally striking, with the US government demonstrating repeatedly that through the threat or actual use of US control over the international monetary and financial regime, it can profoundly negatively affect the economic outcomes of allied economies, disrupting their macro-economic strategies: what I have described elsewhere as the Dollar-Wall Street Regime constructed in the I970s and early I980s (Gowan 1999). Examples of such strategies would include monetary pressure on the French economy to defeat the Keynesian growth strategy of the early I980s and the manipulation of the Dollar-Yen exchange rate to exert intense pressure on Japan's trade position in order to gain an opening of Japanese finance to US financial operators in the I980s and to gain various kinds of managed trade agreements with Japan in the 1990s. Linked to the security pact tactic, the US in the I980s and I99os added the use of economic statecraft in the monetary and financial field to encourage states to 'deal' with it on restructuring its approaches to economic policy and organisation.

Taken together, these levers have enabled the US to 'internalise' the international political economy as Arrighi puts it, to a considerable extent or, to express the same idea in another way, to make significant inroads into the capacity of its allies to manage their own internal affairs autonomously.

\section{The Mistake about US Hegemonic Decline}

Aggregating all these distinctive features of US hegemony, we can see how, when faced with serious challenges to its dominance in capital intensive sectors in the 1970s, the US has a very wide range of instruments essentially derived from its structural power over the inter-state system of the core with which to strike back at competitors. These instruments have been largely ignored or downplayed by mainstream wst. And even Arrighi, who stresses them more than others still remains wedded to the thesis of precipitate US hegemonic decline.

Arrighi's account of the supposed decline focuses upon financialisation. He provides a brilliant account of the way in which earlier hegemonic powers, when faced with defeat in product markets, switched to financialisation and to gaining profits from the competitive success of its rivals. This pattern fits Genoa, Holland and Britain. Chase-Dunn provides a supporting theorisation with his strong emphasis on capital mobility across the inter-state system. He adds to Arrighi's argument by saying that the declining hegemon's domestic capitals are 
not prepared to foot the bill for the mobilisation of state resources to re-subordinate rivals by military means.

Arrighi then suggests that the international financialisation which we have witnessed since the I970s has essentially been a repeat of this earlier cyclical pattern of financialisation. But this has not been the case: quite the opposite. First, the financialisation process was initiated as much by the US state as by US capitals. Secondly, it should be understood as part and parcel of the US state's drive to construct the Dollar Wall Street regime as a weapon for the US fight-back. Thirdly, US leadership of international monetary and financial relations has been a double lever for this fight back: both an instrument of pressure upon other core states, as we have suggested above, but also an instrument for providing the US state with the financial resources for massively strengthening its state military-political capacity in the 1980s.

With all these instruments the US has thus been able to 'hold the line' against its allied competitors and during the 1990 s it has been able to pressure its allies into accepting its own internally generated new leading sectors of capital-intensive industries as the 'hegemonic' industrial driving forces of the new phase of the world economy: the 'information' and telecommunication industries.

\section{PART 2: WST AND THE POSSIBILITY OF CAPITALIST WORLD EMPIRES}

Our critique of WST analysis of contemporary intra-core relations suggests that the scheme of hegemonic cycles in a politically pluralistic core may need structural modification in the light of the characteristics of US hegemony. Some writers, particularly American realists, go much further and insist that the advanced capitalist core today is organised as an American world-empire.

Zbigniew Brzezinski has recently forcefully advanced this argument that today we have US imperial dominance over its European and East Asian allies. He underlines the fact that "the scope and pervasiveness of American global power today are unique....Its military legions are firmly perched on the western and eastern extremities of Eurasia, and they also control the Persian Gulf. American vassals and tributaries, some yearning to be embraced by even more formal ties to Washington, dot the entire Eurasian continent, as the map on page 22 shows" (Brzezinski 1997). What the map in question shows is areas of US 'geopolitical preponderance' and other areas of US 'political influence.' The whole of Western Europe, Japan, South Korea and Australia and New Zealand, as well as some parts of the Middle East and Canada, fall into the category of US geopolitical preponderance, not just influence.

Kenneth Waltz and Paul Wolfowitz have claimed that the Bush and Clinton administrations have been guided precisely by the goal of establishing polit- ical dominance over the rest of the core. The famous 1992 Bush administration document on American Grand Strategy for the post-Cold War world order frankly placed at the very centre of US strategic priorities the subordination of the rest of the core, in the version of the text leaked to the New York Times early in $1992 .{ }^{2}$ This advocated as a central goal 'discouraging the advanced industrialised nations from... even aspiring to a larger global or regional role.' Waltz (2000) points out that despite protests at the time that the document was only a draft, 'its tenets continue to guide American policy.' The chair of the interagency committee which produced the 1992 Grand Strategy, Paul Wolfowitz agrees with Waltz both that the 1992 strategy guidelines have guided US policy and that they have been centred on creating a Pax Americana in the sense of maintaining the subordination of the allies. He adds that 'just seven years later' many of those who criticised the document at the time 'seem quite comfortable with the idea of a Pax Americana... Today the criticism of Pax Americana comes mainly from the isolationist right, from Patrick Buchanan' (Wolfowitz 2000).

The concept of world-empires plays a prominent role in wst. When Wallerstein first launched WST upon the world in 1974 he argued that historically world systems have taken two forms: world economies and world empires. At the start of Volume One of Wallerstein's Modern World System, he draws this distinction very sharply (Wallerstein 1974). A world-economy, he explains, is an 'economic' unit, while a world-empire is a 'political' unit in which one political centre dominated the entire world system.

Chase-Dunn and Hall have modified Wallerstein's original conception, arguing that the concept of a World Empire should be defined as one power dominating the core rather than the entire international division of labour involving the whole periphery as well. As they put it: "There have not been true "world-empires" in the sense that a single state encompassed an entire trade network....rather, so-called world-empires have a relatively high degree of control over a relatively large proportion of a world system. The term we prefer because it is more precise, is core-wide empire' (Chase-Dunn and Hall 1997:210).

They also acknowledge that there have been a series of attempts by capitalist powers to precisely achieve, through war, a capitalist world empire. They mention in particular the Napoleonic attempt and the German attempt in the first part of the $20^{\text {th }}$ century (Chase-Dunn and Hall 1997; see also Chase-Dunn 1998).

2. This was the 1992 Draft of the Pentagon Defence Planning Guide. 
Furthermore, Chase-Dunn (1998), in his book Global Formation, gives an even clearer and more analytically operational concept of a capitalist world empire: he says it is the formation of a core state large enough to end the operation of the balance of power system' ( $\mathrm{P}$. I47). This is precisely the condition which has applied in the core since 1945. Thus, Chase-Dunn's reformulation sharply raises the question whether what we have today is precisely just such a world empire dominating the core.

Yet a consistent and distinctive feature of WST since 1974 has been the insistence of Wallerstein and Chase-Dunn on the theoretical impossibility of a capitalist world-empire.

Thus, even while Chase-Dunn defines a world empire as a condition where a single core state suppresses the balance of power mechanism within the core-a very weak definition of a world empire-he does not acknowledge that the US has effectively achieved this since 1945. And like Wallerstein and other mainstream wST theorists he resolutely argues that in the modern, capitalist world system a core-wide empire is theoretically impossible. We will therefore examine in some detail the arguments of WST theorists as to why a capitalist world empire should be ruled out in the contemporary world.

WST authors reach this conclusion by various significantly different, though overlapping routes. Wallerstein acknowledges that both world economies and world empires seek the extraction of economic surplus. But he says that world empires employ a different mode of extraction, a statist tributary mode, while world economies use market exchange mechanisms. And since, for Wallerstein, market mechanisms are integral to capitalism, capitalist world empires are contradictions in terms. His conclusions as to the impossibility of a world empire are thus contained in his premises. He excludes ab initio the possibility that world empires could be other than tributary states.

\section{As he explains:}

Political empires are a primitive means of economic domination. It is the social achievement of the modern world, if you will, to have invented the technology that makes it possible to increase the flow of the surplus from the lower strata to the upper strata, from the periphery to the center, from the majority to the minority, by eliminating the "waste" of too cumbersome a political superstructure. (Chase-Dunn I998:15-16)

In Rise and Demise Chase-Dunn and Hall make a similar point. They state: 'Capitalists prefer a multicentric international political system. Hence the most powerful states in the modern inter-state system do not try to create a corewide empire but seek rather to sustain the interstate system. This is because their main method of accumulation is commodity production, which contrasts with precapitalist systems, in which state power itself was the main basis of accumulation, through taxes or tribute. Phrased differently, capitalist states are qualitatively different from tributory states' (Chase-Dunn and Hall 1997:33; see also Chase-Dunn 1990). This argument is re-iterated in slightly different terms towards the end of their book, when they say that in the modern world system unlike earlier ones, a hegemonic power 'never takes over the other core states. This is not merely a systematic difference in the degree of peak political concentration. The whole nature of the process of rise and fall is different in the modern world-system. The structural difference is primarily due to the relatively much greater importance that capital accumulation has in the modern world system' (Chase-Dunn and Hall 1997:210).

There is, indeed, a slightly different stress here from Wallerstein, particularly in the implicit idea of Chase-Dunn and Hall that core capitalists will display solidarity against a world empire being established by a hegemon since it would restrict their freedom of movement as capitals and block their scope for exploiting inter-state arbitrage, a point to which we will return.

But in Chase-Dunn's earlier book, Global Formation, he provides a much more specified and testable series of arguments as to why the modern capitalist core will successfully resist the establishment of a world empire. His argumentative route passes from an initial acceptance that a capitalist core-wide empire involving capitalist market exchange is in principle possible to deploying a series of arguments to the effect that there are overwhelmingly powerful forces built into the structure of the modern world system preventing this theoretical possibility from occurring. Some of these arguments derive resistances to world empire from structural characteristics of the inter-state system in the modern world. Others focus upon structural features of capitalism as an economic and social power system of production and upon the derived interest perceptions of capitalists.

While Chase-Dunn presents his argumentation as a set of reasons why a core-wide empire is impossible, we can re-angle his claims to present them as the necessary preconditions for achieving a core-wide empire. Some of these are preconditions in the inter-state system; others are preconditions concerning capitalist impulses and interests. We can summarise these as follows:

a. Inter-state system preconditions:

I. An empire-state would have to be strong enough to suppress the balance of power system and establish a unipolar organisation of core politics.

2. It would have to find ways of preventing the diffusion of military technologies to other core states, to prevent them mounting a military challenge to the empire-state. 
3. It would have to be able to suppress the possibility of other core states using their sovereignty to experiment and innovate to challenge the hegemon in the productive field.

4. It would have to be able to prevent counter-tendencies and movements towards world government from other core capitalists and states, perhaps in alliance with other, subordinate social groups.

b. Capitalist interest/incentive pre-conditions:

I. It would have to prevent international capitalists from ganging up to weaken its control over the international political economy in order to protect their own freedom of movement and of operations from its predatory demands.

2. It would have to convince international capitalists that the worldempire would avoid undermining the basis of capitalist social domination within other core and periphery states, avoiding, for example, the possibility of transnational anti-systemic movements challenging both the empire and capitalism.

These arguments of Chase-Dunn are important. We can agree that many of them do indeed offer us a theory of the pre-conditions for a secure, long-term, core-wide empire highlighting important internal tensions in any such project. But after examining each in turn, we will question some of the premises underlying Chase-Dunn's theorisation.

Inter-state Preconditions: The maintenance of unipolarity in the core, preventing other core states from allying against the world-empire project is clearly a fundamental precondition. But Chase-Dunn's argument that the empire state would have to prevent the diffusion of military technological knowledge across the core-something that Chase-Dunn considers impossible in the modern world-is surely one-sided. The empire state would simply have to maintain at any one time a decisive technological lead sufficient to deter any challenge at any given time. This would indeed be a precondition but one linked as much to relative resources for military research and development as to capacities to block information flows in this area.

The third point in this area-suppression of effective competitive challenges in the productive sector from other sovereign core nation states-is clearly fundamental. We can express this as the ability of the empire state effectively to control socio-economic developments and outcomes within juridically sovereign core states. Many would regard such a task as a contradiction in terms and thus a decisive basis for ruling out a world empire in which juridically sovereign states are retained in the core. We shall return to this subject later.
The fourth point-the world-state's ability to prevent the other core states from transforming the world dominated by a single empire-state into a world state is also, of course, fundamental.

Capitalist interest/incentive preconditions: This set of arguments essentially rest upon the idea that the interests/incentives of core capitals including those of the incipient empire state would be radically opposed to any such world empire project because of the systemic needs of capitalism as such. As Chase-Dunn and Hall (1997:33) put it in the quotation above, 'capitalists prefer a multicentric international political system.' They do so for both economic and political reasons.

Freedom of international movement of capital is important both to exploit unevenness and as a decisive source of structural power over geographically immobile labour. Both depend upon real competition between core states in the international political economy. This competition offers capital the chance for regime arbitrage across states, checks the ability of any state, not least the empire-state, to impose restrictions and extra fiscal and other burdens on capital and drives labour constantly to accept restructuring of production within any state for fear of capital migration. Thus the maintenance of inter-state competition is necessary for the preservation of the social domination of capital.

But the inter-state system is not only a lever for negatively disciplining the working class and other subordinate groups in the economic system. It also provides a basis for subordination through providing strong 'vertical' political identities between different social groups within a given state: identities based on the supposed priority of racial/ethnic, cultural, or religious bonds between social classes within the state overriding other social divisions. The resulting 'state-worship' based upon the state's supposed embodiment of the values of the ethnic, cultural or religious community is a further source of social subordination to the rule of capitalism and one that depends upon the maintenance of the authority and capacity of nation states and thus of the inter-state system. Insofar as a set of core nation states seemed to be subordinated to an empire state, there could be the risk of movements by subordinate classes across core states to mount challenges to the empire state with potentially anti-capitalist dynamics.

These arguments carry great force. But they rest quite strongly upon two premises. The first is that world-empires and sovereign states are necessarily mutually exclusive, polar opposites. And the second is that there is a structural tension between capitalists and states which a fortiori must be particularly strong as between capitalists and an empire state. Both these premises are weak in the contemporary world. 


\section{A World Empire of Juridically Sovereign States?}

The liberal tradition tends to place juridical relations on a higher plane than political relations. It thus assumes that a world empire in a political sense presupposes juridically imperial relations. The European Empires of the first half of the $20^{\text {th }}$ century were indeed juridically anchored and liberalism typically assumes that their replacement with a new juridical order of sovereign states encompassing the globe ended possibility of an era of empires of any kind.

But this concept of an empire presupposes that an imperial relation is one of hierarchical command-compliance: a centre gives an order and the subordinates follow it - a juridical empire is simply the most formalised form of such an hierarchical command empire.

But a systems approach to the organisation of politics and political economies can offer us a very different, more indirect but also more robust and effective form of imperial control, one in which the empire state has sufficient capacity to design the core as a system of inter-actions which systematically tends to produce outcomes re-enforcing the power and interests of the empire-state.

Joseph Nye (1990) discusses this variant in his book, Bound to Lead, as follows:

Command power can rest on inducements ("carrots") or threats ("sticks").

But there is also an indirect way to exercise power. A country may achieve the outcomes it prefers in world politics because other countries want to follow it or have agreed to a system that produces such effects. In this sense, it is just as important to set the agenda and structure the situations in world politics as it is to get others to change in particular situations. This aspect of power-that is, getting others to want what you want-might be called indirect or cooptive power behaviour. It is in contrast to the active command power behaviour of getting others to do what you want (I990: 3I).

One central consequence of Nye's concept is that it suggests the possibility that a world empire can be an inter-state system and international political economy shaped and structured in ways that generate empire-state re-enforcing agendas and outcomes. We can call this an Empire-System.

Let us take some simple examples of how an Empire-System could work. If the empire state can shape the geopolitical environment of other core states in such a way that their security is threatened in ways that require the military resources of the empire state, these other core states will want what the empirestate wants. Or if the other core states' financial sectors' stability is bound up with the safety of their loans to empire-state companies and individuals whose prosperity in turn hinges upon rising prices on the empire-state's securities markets, those other core states will want what the government of the empire- state wants: a priority for stability on the empire-state's financial markets. Or if other core states' capitals view their continuing expansion as dependent upon further opening of 'emerging markets' in the semi-periphery and if the most potent instrument for such opening is the empire-state's manipulation of the international monetary and financial regime, the other core states will want what the empire state wants.

Of course, in reality, a core-wide empire in contemporary conditions would not be exclusively an Empire-System of this sort. It would also possess various instruments of command power and indeed of covert action and surveillance within the core to assure its dominance. But the main form of its dominance would be indirect, of the Empire-System type, even if the Empire-System rested upon foundations of extraordinary military-political capacity and reach.

\section{The Empire State as Friend or Foe of Capital?}

The idea that there is a deep antagonism between private business and the state runs deep in Anglo-American liberalism and it has been radicalised in the neo-liberal ideologies of the contemporary period. This preconception can lead one to think that capital would be especially hostile to an imperial super-state.

One referent for this supposed antagonism lies, of course, in the counterposition between private-property-market mechanisms of supplying goods and services and state provision of goods and services. But to define the capitalist state as first and foremost a provider of goods and services is, to say the least, somewhat one-sided. Another referent is the trade-off between state revenue and retained private income. But this can scarcely be seen as a radical opposition between state and capital given that the bulk of such taxation is spent upon infrastructures necessary for the reproduction of the private sector itself.

There are, of course, very strong grounds for arguing the opposite case, namely that in the contemporary core there is a symbiotic relationship between capitalist states and capitalist classes. Arrighi has stressed closeness of this relationship pointing out that markets are simply a mediating level in capitalist reproduction rather than an autonomous governing framework for capital accumulation. He emphasises this with some striking formulations by Braudel on the relationships between capitalism and markets.

Braudel argues that the market should be seen as the 'middle layer' of the modern economy; beneath it is the layer of production and subsistence; and above it is the layer which Braudel calls capitalism-or as he expresses it, the 'anti-market.' Braudel (1982) says of this: "Above [the lowest layer], comes the favoured terrain of the market economy, with its many horizontal communications between different markets: here a degree of automatic co-ordination 
usually links supply, demand and prices. Then alongside, or rather above this layer, comes the zone of the anti-market, where the great predators roam and the law of the jungle operates. This-today as in the past, before and after the industrial revolution-is the real home of capitalism" (PP. 229-230). Elsewhere Braudel (1977) adds: 'Capitalism only triumphs when it becomes identified with the state, when it is the state' (pp. 64-65).

In this context, it is perfectly possible to envisage possible bases for strong co-operation between the capitals of the core and an emergent empire-state. Let us mention some of them:

a. If the empire-state presents itself as the champion of the most unrestricted rights of capital over labour within all the states of the core, this empire state should expect a warm reception from capitals across the core.

b. If the empire-state offers itself as an instrument for expanding the reach of all core capitals into the semi-periphery and periphery it should also expect a warm reception from capitals across the core.

c. If the empire-state offers a new model of capitalist organisation which brings very large additional pecuniary rewards to leading social groups within other core states it can hope to create a broad constituency of social support in the business classes across the core.

d. If the empire-state offers a mechanism for managing the world economy and world politics which is sufficiently cognisant of trans-core business interests the empire-state may be strongly preferred to the risks of institutionalised world government by core business and political elites.

In conclusion, insofar as Chase-Dunn is arguing that a precondition for a capitalist world empire is that the empire-state must be perceived by strategic sectors of core-wide capital as its champion, we could agree with him. But insofar as he argues that this is a theoretical impossibility we would disagree.

WST theorists do not seem to have adequately explored the possibility that within the Modern World System, a core wide empire is, under certain conditions, very much a theoretical possibility. The key attributes of a state seeking to become an empire-state in contemporary conditions are:

a. It must have the resources to organise its empire as a System-Empire not just as a Command (or juridical) Empire.

b. It must have the capacity to rally strategic constituencies of core-wide capital to its empire project.
Of course, the long-term sustainability of the world empire would require many other pre-conditions: the empire-state would have to use its extraordinary dominance to ensure the continued ascendancy of its capitals in key production sectors. It would have to assure its capacity to extract sufficient resources from the reproduction process to sustain its military-political reach and ascendancy and it would be faced by the constant danger that its own public policy blunders could drag it down to defeat.

We will now turn to consideration of whether such an empire actually exists, as Zbigniew Brzezinski would have us believe.

\section{PART 3: CURRENT INTRA-CORE DYNAMICS: THE UNITED STATES AS A NEW WORLD-EMPIRE?}

One of the most striking areas of weakness in Western social science analysis in the last quarter of a century has been its inability to reach anything like a stable, minimal agreement on the role and capacity of the United States in international relations. Within a decade opinion has swung wildly from images of the US as being in terminal hegemonic decline to images of it as a colossus dominating the planet. And there has generally been no minimal agreement, even within each of the various intellectual paradigms on the criteria for making analytical judgments on this topic.

Mainstream wST at least has had the merit of maintaining over decades a fairly clear and stable set of theoretical and analytical criteria for approaching this topic. It has ruled out the theoretical possibility of a world empire, it has provided clear criteria for identifying hegemonic status and it has judged, on the basis of its criteria that since the I970s the US has been in hegemonic decline.

The performance of American capitalism in the 1990s would also seem to provide WST with evidence that the United States is bouncing back and has entered a phase of hegemonic revival-something not excluded as a possibility in WST. In the capital intensive information and telecommunication industries which seem to be revolutionising international economics, the US seems to possess a substantial competitive advantage. And more than ever it seems to possess the military-political capacity to ensure the diffusion of its products in these fields on a global scale.

But our analysis in this paper suggests that the United States occupies a place within the contemporary core qualitatively different from the place suggested by the concept of hegemon which mainstream wst advances. It possesses strong elements of what we have called a capitalist world empire.

We will focus here on some critical issues on which a judgement of the nature of US dominance would depend. We argued above that the success of 
the American state's project for establishing and consolidating a capitalist world empire must depend upon achieving four critical goals:

a. It must have the capacity to rally strategic constituencies of core-wide capital to its empire project.

b. It must have and must be able to deploy effectively the resources to organise its empire as a System-Empire not just as a Command Empire.

c. Success in these two fields must be complemented by its ability to sustain, in the long term its ascendancy in the most dynamic sectors of capital-intensive production.

d. Success must also include an effective set of mechanisms for demonstrating that such an empire-system is optimal for managing transnational class relations between capitalism and subordinate classes, coping with future anti-systemic movements.

\section{International Social Coalition Building}

In pursuing its world-empire project over the last twenty years, the United States' business and political elites have sought to rally support as the champions not just of American business interests but of business interests and the strengthening of capitalism as a social system on a world-wide scale. This, we have argued, is a necessary condition for any capitalist world-empire project.

On the face of it, this task might seem a daunting one. After all, every European or Asian business person knows very well that the US government aggressively supports its own businesses against the international competition wherever it can, a feature that has been particularly pronounced in the Clinton administration. Yet the US has shown that it has very great capacities to present itself as the leader of global capitalist interests in a number of ways:

a. The champion of the rights of capital over labour. Business in other parts of the core and semi-periphery is not simply or mainly pre-occupied with competitive challenges from US businesses. It is daily concerned with maintaining its stable social ascendancy over labour. The US stands as an example and a champion of the most unrestricted rights of capital over labour within all the states of the core. Its programmes processed through the IMF and World Bank in the former Soviet Bloc, in semi-periphery and periphery demonstrate that. And its programmes for privatising utilities, freeing transnational private financial operations, placing the financial sector in the driving seat and re-accenting capitalism towards securities-market centred, share-holder value buttressed by private pension funds has great attractions for core capitalists. The US pro- gramme offers very substantial rewards to the rentier interests of business executives and others. Thus, insofar as the German government fully adopted the US programme for shareholder capitalism, a German business executive could hope to see his or her income at least doubling.

b. Strengthening Core Capital's Expansion into the Semi-Periphery and Periphery. A second very important basis for the US being able to present itself as the champion of core capital as a whole lies in its ability to demonstrate its leadership on the global expansion of core capitals into regions outside the core. Since the days of the Reagan administration, the US has driven forward a programme which offers the semi-periphery and periphery only one path towards economic development: that of opening its domestic assets to the entry of core capitals for FDI-led growth and for portfolio inflows to compensate for domestic financial and fiscal strains. This has been a powerful programmatic link between the interests of the United States and its businesses on the one hand and the businesses of the rest of the core on the other.

c. Bargaining Power with the Strongest non-American Core Businesses. A much more narrowly focused but extremely important aspect of US coalitionbuilding is its ability to accept or deny the most influential groups of multinational corporations based in other core states secure insertion into the US market itself. Any European or Japanese company seeking global ascendancy in its sector must gain a strong, secure presence within the United States. Achieving this is as much a political as a purely economic task. The capacity of the Deutsche Bank to buy a large German bank or of Daimler Benz to buy a large US car producer depends upon a willingness to accept American approaches to developments in their own countries, for example, a readiness on the part of the Deutsche Bank to move away from the closed system of German corporate governance involving inter-locking bank-industrial structures. The same applies to Japanese companies.

d. Being able to resist pressures from other parts of the core for collegial, institutionalised forms of global government by offering core capitals sufficient scope for their own expansion within an empire-state framework of global governance.

This has been, perhaps, the most sensitive area in the efforts of the US to consolidate its global social coalition in the I99os. Its operations in international monetary, financial and trade and investment policy at an international level have frequently aroused suspicion on the part of the capitals as well as the governments of other parts of the core that US power is being used narrowly to favour its own capitals and clients. Rather than opting for a capitalist world empire, capitalists are, in the view of Chase-Dunn and Hall, more likely to accept moves towards world government, despite the risks these steps could 
involve of generating social movements challenging the capitalist market. Thus, in Rise and Demise, speaking of the weak forms of global governance supplied by the Concert of Europe, the League of Nations and the UN, Chase-Dunn and Hall (1997) continue: "Though these weak forms of global governance did not much alter the pattern of hegemonic rise and fall in the cycle of world wars over the past 200 years, the spiraling strengthening of global governance might, if it continues, eventually lead to a world state that can effectively prevent warfare among core states' (240). But they underestimate the extent to which the worldempire project can remain an attractive alternative even for the capitalists of competitive core states. One of the reasons for that attractiveness is precisely given by Chase Dunn and Hall when they point out a world state would likely be dominated by the hegemony of global capital for a time. However, if the fascist alternative were avoided, it might undergo a reform process that would lead to global democratic socialism' (Chase-Dunn and Hall 1997:240).

At a more immediate level, a powerful compensating factor mitigating resentments among other core capitals against US economic nationalism has been the boom in the American economy itself, which has offered wide profitable opportunities for capitals across the core and which has thus eased international business tensions.

All these factors, then, have enabled the United States to gain very broad social support from the business classes of the rest of the core for its worldempire project in the I990s. No clearer demonstration of that is needed than the fact that the media empires of the core have been prepared to thematise the American project not as a Pax Americana but as an agentless process of 'globalisation' that we must all accept and live within.

\section{Progress Towards an Empire-System}

We have argued that in the contemporary world, a core-wide empire cannot be sustainable simply as a Command Empire, whereby the empire-state is reliant upon carrots and sticks to maintain its dominance over the rest of the core. These command capacities should be confined largely to crisis situations while the normal functioning of the order leaves them in the background and can rely upon the shaping of the power-relevant environments of other core powers to make them 'want what the US wants' in the phrase of Joseph Nye. We will now investigate the extent to which the US has been able to advance and consolidate this Empire-System in the I99os.

a. Preventing Other Core Powers from Gaining Regional Geostrategic Autonomy. The Bush administration's 1992 Grand Strategy document was surely right to prioritise the risk of the West European and Japanese parts of the core acquiring regional political autonomy. One very important dimension of this is geostrategic autonomy. This could be achieved through Germany leading Western Europe into a strategic security partnership with Russia and through Japan entering a strategic security partnership with China. Such partnerships would not, of course, be directed against the United States. They would simply give priority to the formation of a security community of the states involved. In the event of achieving this, the relevant core states would lose their geostrategic dependence on the US relationships respectively with Russia and China.

During the I990s, the US has successfully prevented this eventuality from arising. The exclusion of Russia from an enlarging NATO striking out of area at a state with friendly relations with Russia-namely Serbia-in the Kosovo war has indeed gone a great distance towards rebuilding Europe's bipolar structure. At the same time the United States has been strengthened in its efforts to secure a belt of pro-US states between Russia and Germany. A further step to consolidate this pattern of Western Europe's strategic dependence on the US would, paradoxically, need to be for the US to have the capacity to demonstrate to Russia that its position in the international order can best be secured through privileging its relations with the US rather than with Germany and Western Europe.

In the Pacific region, there is little risk of Japan seeking to break out of its strategic dependence upon the United States-China relationship because of the many potential conflicts of political interest with a China which is becoming increasingly powerful within the whole region.

b. Preventing European Political Unity. A very important and too little recognised feature of US political dominance in Europe during the Cold War was the fact that NATO Western Europe was actually politically fragmented with each fragment having its main political link with the US rather than with other West European fragments. The EU created the illusion that this was not so. This political fragmentation of Western Europe has continued through the I99os, but significant counter-tendencies are emerging, focused upon a much more political Franco-German axis. The driving forces behind these tendencies lie first in the common commitment to the Euro and to giving it an adequate political anchorage; and secondly, in the common concern at their vulnerability to events in East Central South Eastern and Eastern Europe which the West European states do not control (and which the United States exerts increasing influence over). These pressures are leading to efforts to build an inner core within the EU and to giving that core (with or without Britain) some collective military capacity. This shows it to be a cohesive political group around the Euro, turns it towards being a West European caucus within NATO and gives it, through its collective military instruments, the potential to wield greater influ- 
ence around Western Europe's immediate hinterland. A secure world-empire would need to contain such pressures.

c. Preventing Pacific Regional Political-Economy Integration. The greatest challenge to a consolidated World Empire in the Pacific region would come from the capacity of Japan and China and the ASEAN states to form a stable regional political-economy bloc, whether involving monetary and financial integration or a so-called 'Free Trade Area' (i.e. a zone of relatively protected investment and trade linkages). The United States, whose economic penetration of the region has been weak, has worked hard to prevent such a development. It succeeded triumphantly (with West European support) in preventing Japan from establishing a regional financial and monetary shield in the autumn of I997 and in subsequently greatly strengthening US economic penetration of the region as a result of the financial crisis of 1997-8 and the IMF (i.e. US Treasury) policies in that crisis. But Japanese efforts to build such a financial and perhaps monetary shield have been relaunched in 2000, with support from China and with some initial success. Nevertheless, access to the US market remains sufficiently critical for so many of these economies that the US retains substantial leverage at a political-economy as well as a military-political level.

d. Maintaining International Monetary and Financial Leverage. A US World-Empire project would have to combine the military-political dimension with continued dominance over international monetary and financial relations. Both Japan and Western Europe have taken steps, in different ways, to protect themselves from the US use of economic statecraft in this field to exert pressure on the rest of the core.

In the West European case, this has been attempted through the European Monetary System and its successor, the Euro. The final implementation of the Euro in July 2002 will supply a very substantial shield for Western Europe, particularly when it is combined with an integrated deep and liquid EU financial system. The strength of this shield will be all the greater in that, despite all the talk of economic globalisation, the European economy is becoming an increasingly closed one, less and less reliant upon transatlantic trade.

As far as Japan is concerned, it has not made any serious attempt to turn the Yen into a significant international reserve currency or to construct a yen bloc as a shield against US economic statecraft. This would be too risky a step, threatening heavy retaliation. Instead the Japanese government has used its enormous financial power to build up very large positions in the US financial market, especially in the Treasury bond markets. Such is the size of these Japanese holdings in the dollar area that their liquidation could deliver a substantial shock to the dollar. In other words the Japanese government has acquired leverage over US dollar policy. e. Gaining Strategic Control over the International Division of Labour. A fullyfledged World-Empire project would give the United States the capacity not just to use the market mechanism to assure its ascendancy in product and services markets but to acquire a more structured ascendancy in the markets of the rest of the core. Yet there is continued resistance to efforts in this direction from both Japan and Western Europe. One striking symptom of this is the instability and tension surrounding the functioning of the World Trade Organisation. Another is the series of battles raging over biotechnology industries. A third is the very important conflicts over corporate governance issues and the capacity of foreign capitals to engage in hostile takeovers of important domestic companies. A fourth is the constant efforts of the US to enlarge the reach of US domestic jurisdiction over the political economies of the rest of the core.

The general direction of US policy in these areas is that of re-engineering the internal social relations of the rest of the core in such a way as to enable US capitalism to use its huge financial resources to be able to centralise and concentrate capital effortlessly across the core in the sectors considered vital for US ascendancy. But the US is still a long way from achieving this even if it has progressed far down this road in the case of Britain.

This is the area where a capitalist world empire does seem to reach its limits as a result of the necessary continued existence of an inter-state system of parcelised legal sovereignties within the core. The capacity of other core states to use their legal and administrative autonomy as well as their economic capacity and cultural/political identities to resist pressures in this area has been demonstrated in the cases of both Japan and Germany over the last two decades. This capacity for resistance is not limitless. The Japanese financial crisis of $1998 \mathrm{dem}$ onstrated the US's ability to enlarge the frontier of its penetration into Japan. But it remains very great.

\section{Assuring US Ascendancy in the Field of Production}

The extraordinary advances made by the United States during the I990s have received great impetus from both the macro-economic dynamism of the US economy in the context of continuing stagnation in Japan and Western Europe and from the perceived emergence of a new wave of growth-generating capital-intensive industries within the United States. These two factors have dazzled the capitalists of the rest of the core. But they may not be as solidly based as they seem.

There is now widespread agreement that the US boom has been fed by some features which are not only unsustainable but potentially very dangerous: a strongly speculative boom on the stock market which itself has become 
an ever-more central mechanism in the American economy, a huge growth in private indebtedness, with much of the debt being tied to stock market speculation, and very large levels of US international debt and US trade deficits. A sudden shock could therefore swiftly transform the boom into a very savage financial crisis and deep recession with multiple consequences for the world economy.

Secondly, the supposed new growth motors of information industries and telecommunications may not have the long-term effects of sustained productivity gains necessary for what wsT theorists call the A Phase of a new K-wave, in other words a new long boom anchored in a new US hegemony in the key productive sectors. Studies of the impact of information technology on productivity do not indicate unequivocally its capacity to be the necessary growth motor for a new long boom.

Thirdly, there are very real doubts about the new American business system of share-holder value. While this system is extremely attractive at a pecuniary level to business classes throughout the core and while it offers great opportunities for US money capital to extend its sway over productive assets in other countries, there must be serious doubts as to whether it is an effective business system for generating long-term large investments in fixed capital, geared to sustaining US innovation and productive ascendancy. If German and Japanese capitalisms can resist the seductions of dramatic short-term financial gains and maintain business systems more geared to long-term investment in innovations they may well be able to remount a challenge to the US in the productive sector quite rapidly (O'Sullivan 2000).

\section{Coping with Future Anti-Systemic Movements}

Too often overlooked in assessments of American resurgence in the I99os has been one absolutely central feature of the period: the collapse of Communism. This has not simply led to a scramble for gain in the former Soviet Bloc, it has given a unique accent to transnational class relations because it has resulted in the disorientation and disorganisation of labour on an international scale. This has been a fundamental social basis for the extraordinary advance of the new Pax Americana or empire project.

That project's advance has required that the states and capitalist classes of the rest of the core find it relatively risk free to accent their efforts towards bandwaggoning with the US programme of unfettered capitalism, American style. The weakness of labour has made that emphasis relatively easy to achieve. But in the event of a restabilisation of labour and renewed pressure from that quarter, core and semi-periphery capitalist states will face a trade off between making further adaptations towards the regime goals of the US and making adaptations to the domestic pressures from labour, even if, at the cost of disrupting US regimes. A process can occur somewhat similar to the processes leading to the disintegration of the Gold Standard and free trade in the interwar period as states in Europe had to cope with the rise of labour then. And, of course, core and semi-periphery states can also use the risk of a challenge from labour as a way of resisting US pressures to accept imperial regimes.

While a revival of the strength of labour may seem to many a fanciful prospect at this moment of post-modernist play and senses of endings there remain both strong sociological and economic bases for such a resurgence and also still very substantial resources of the most subversive strands of the modernist project available for challenging the narrow strip of liberal individualist universalism through which the current imperial project is ideologically legitimated.

Such a revival of the challenge from labour could also be used by core powers to advance a programme of more collegial and institutionalised world government against the unipolar, US-governance instruments which have been unchallenged in the ig9os.

\section{CONCLUSION}

WST's historical theorisation of intra-core relations has been a very great scientific achievement. It provides us with a comprehensive research agenda on this topic, even if it underplays the radical differences between the hegemony of Britain and the United States, down-grades some central features of US hegemonic capacities and rules out too glibly the possibility of a contemporary capitalist world empire. Furthermore, the work of Arrighi contains many insights and leads upon which to draw for developing a more adequate analysis of contemporary dynamics. And Chase-Dunn's and Hall's work has helped to transform wST's study of these issues from being a brilliant schema outlined by Wallerstein into a very serious scholarly research programme.

\section{REFERENCES}

Braudel, Fernand. 1977. Afterthoughts on Material Civilization and Capitalism. Baltimore, MD: Johns Hopkins.

Braudel, Fernand. I982. Civilization and Capitalism, $15^{\text {th }}-18^{\text {th }}$ Century, Volume III: The Wheels of Commerce. New York: Harper \& Row.

Brzezinski, Zbigniew. 1997. The Grand Chessboard: American Primacy and its Geostrategic Imperatives. New York: Basic Books.

Chase-Dunn, Christopher. 1998. Global Formation: Structures of the World-Economy. Lanham, MD: Rowman and Littlefield. 
Chase-Dunn, Christopher. 1990. "World State Formation: Historical Processes and Emergent Necessity." Political Geography Quarterly, 9(2): 108-30.

Chase-Dunn, Christopher and Thomas D. Hall. 1997. Rise and Demise: Comparing World-Systems. Boulder, CO: Westview Press.

Gowan, Peter. 1999. The Global Gamble. London: Verso.

Huntington, Samuel P. 1973. "Transnational Organisations in World Politics," World Politics, 25(3):333-368.

Kahler, Miles. 1995. Regional Futures and Transatlantic Economic Relations. New York: Council on Foreign Relations Press.

O'Sullivan, Mary, 2000. Contests for Corporate Control: Corporate Governance and Economic Performance in the United States and Germany. Oxford: Oxford University Press.

Nivola, Pietro. 1993. Regulating Unfair Trade. Washington, DC: Brookings Institution.

Nye, Joseph. 1990. Bound to Lead: The Changing Nature of American Power. New York: Basic Books.

Rothkopf, David J. 1998. Beyond Manic Mercantilism. New York: Council on Foreign Relations.

Wallerstein, Immanuel. 1974. The Modern World System I: Capitalist Agriculture and the Origins of the European World-Economy in the $16^{\text {th }}$ Century. New York: Academic Press.

Wallerstein, Immanuel. 1984. "The Three Instances of Hegemony in the History of the Capitalist World Economy," in Current Issues and Research in Macrosociology, International Studies in Sociology and Social Anthropology, vol. 37, edited by Gerhard Lenski. Leiden: Brill.

Waltz, Kenneth N. 2000. "Globalization and American Power." The National Interest, 59:46-56.

Williamson, John. 1977. The Failure of International Monetary Reform, 1971-74. London: Nelson.

Wolfowitz, Paul. 2000. "Remembering the Future." The National Interest, 59: 35-45. 